\title{
Does the Labor Market Structure Explain Differences in Poverty in Rural Punjab?
}

\author{
Rashid Amjad, G. M. Arif and Usman Mustafa*
}

\begin{abstract}
The main focus of this study is Rural Punjab and it contributes to regional poverty research in two ways; first, using a more recent household survey data, carried out in August 2007 by the Pakistan Institute of Development Economics (PIDE), it provides fresh poverty estimates for the rural areas of the Punjab. Second, the poverty differential across the agroclimatic zones of Punjab have been explained by urbanization, overseas migration and the labor market structure operating in these zones. This study shows four major factors that explain inequalities in poverty levels. First, the rural areas of two zones, barani and rice/wheat, are well integrated with urban settings. This integration has allowed their rural populations to work in the industrial sector of Central Punjab and the services sector in North Punjab primarily Rawalpindi and Islamabad. Second, the belt from Lahore to Attock in the Punjab has benefited the most from overseas migration. The flow of remittances has helped in reducing poverty levels. Third, the cotton/wheat and low intensity zone still largely depend for employment on the agricultural sector while this dependency is very low in the barani zone, which has good opportunity to seek job opportunities for its labor force in the armed services and government departments. Finally, demographic and social factors including education are less favorable in the cotton/wheat and low intensity zones which negatively impacts on a breakthrough in poverty reduction.
\end{abstract}

JEL Classification: D33, J20, J61

Keywords: Pakistan, Poverty, Migration, Labor Market

\footnotetext{
* Rashid Amjad is the Vice Chancellor of Pakistan Institute of Development Economics (PIDE), G. M. Arif is the Dean, Faculty of Development Studies and Usman Mustafa is Chief, Training Programme and Project Evaluation Division of PIDE. Authors are thankful to Mr. Masood Ishfaq, Muhammad Kamran Khan and Ms. Amena Urooj from PIDE for their help in data analysis. Typing assistance from Mohammad Sarwar is also acknowledged.
} 


\section{Introduction}

The poverty debate in Pakistan has centered on trends in the headcount ratio. However, regional poverty differences, particularly within the rural areas, have been neglected. It has been well documented in studies carried out over the past two decades, which have utilized nationally representative as well as special small surveys, that poverty in some regions, for example barani Punjab (rural), is lower than in other regions particularly the cotton growing zones of Punjab and Sindh. Consistently low-levels of poverty in barani Punjab are largely attributed to certain socio-economic characteristics of the region such as integration of its rural areas with the prosperous urban centers, relatively better human capital, access to jobs in the armed forces and government departments located in Capital city of Islamabad, and its long tradition of overseas migration. However, there is little empirical work showing these relationships.

This study contributes in the regional poverty research by two ways; first, by using a more recent household survey data, carried out in August 2007 by the Pakistan Institute of Development Economics (PIDE), it provides fresh poverty estimates for rural areas of Punjab. Second, the poverty differential across the agro-climatic zones of Punjab have been explained by urbanization, overseas migration and the labor market structure operating in these zones.

Rural Punjab is the focus of this study, and it is organized as follows. After the brief introduction, the review of literature is presented in the next section, followed by theoretical considerations in section 3. A discussion on recent poverty estimates is presented in section 4 . Section 5 presents a short discussion on factors that can explain poverty differences across zones, including urbanization, overseas migration, employment structure and human capital. Concluding remarks are given in the final section.

\section{Setting the Context: A Review of Literature}

The earlier studies that found significant differences in poverty levels across agro-climatic zones include Malik (1992), Arif and Ahmad (2001), Malik (2005) and Irfan (2008). A common feature of these studies is that they have used the methodology of Pickney (1989) to classify rural areas into zones/regions. Pickney classified the entire country into nine agro-climatic or crop zones based on Kharif crops (cotton and rice mainly) because wheat is the predominant crop in Rabi season virtually in all areas of the country. These zones are named as rice/wheat Punjab, mixed Punjab, cotton/wheat Punjab, barani Punjab, low-intensity Punjab, cotton/wheat Sindh, rice/other 
Sindh, NWFP except D.I. Khan, Balochistan except Nasirabad. ${ }^{1}$ The other common feature of the earlier studies is that they are based on micro (or household-level) nationally representative datasets, carried out during the last two decades by the Federal Bureau of Statistics (FBS), although Arif and Ahmed (2001) have also used a survey managed by the PIDE in 1998-99. It is worth noting that all these datasets may not be necessarily representative at the agro-climatic zone level.

The major similarity in the findings of all these studies is that the lowest levels of poverty are found for barani Punjab (Appendix Table-2), consisting of currently five northern districts of the province, Rawalpindi, Jhleum, Chakwal, Attock and Islamabad. Concerning the other zones, Malik (1992) found the highest incidence of poverty in cotton/wheat Punjab, followed by Balochistan and rice/other Sindh in 1984-85. This order, according to Malik, changed to low intensity Punjab followed by cotton/wheat Punjab and rice/other Sindh in 1987-88. Arif and Ahmed (2001) estimated that cotton/wheat Sindh and rice/wheat Punjab were the poorest regions in 1993-94 and 1998-99. For the 2001-02 period, Malik (2005) found that Sindh and Southern Punjab were the poorest regions of Pakistan. According to the recent work of Irfan (2008), based on the 200405 PSLM data and official poverty line, cotton/wheat zone of Punjab is still the poorest region followed by NWFP and low intensity Punjab.

A few other studies that have used different approaches for the classification of Punjab districts into regions have reached to similar results. For example, the FBS, which divided Punjab into three regions, north, central and south, substantiate these findings, and shows the highest levels of poverty in southern Punjab and lowest in northern Punjab, representing respectively the cotton/wheat and barani zones of Punjab (GoP, 2003). Results of the study carried out by Gazder, et. a1. (1995) based on the two datasets also support this view. ${ }^{2}$ They desegregated rural Punjab into north and south and indicated that rural south Punjab had an extremely high incidence of poverty - significantly higher than in rural north Punjab. More recently, using the district-level representative Multiple Indicator Cluster Survey carried out in Punjab in 2003-04, Cheema (2008) has reported the results of an on-going study in Dawn (April 7, 2008) and shows that poverty is concentrated in the southern districts of Punjab. He found a low incidence of poverty in the districts of Sialkot, Jhelum, Rawalpindi, Chakwal, Gujrat, Lahore and Attock - four of which are in barani Punjab zone. The

\footnotetext{
${ }^{1}$ Classification of districts in these zones is shown in Appendix Table-1.

2 1990/91 Household Integrated Economic Survey (HIES) and 1991 Pakistan Integrated Household Survey (PIHS). (Also cite these references)
} 
findings of socio-economic ranking of districts are also similar to the poverty research (Jamal, et a1. 2003).

\section{Theoretical Considerations}

Although several factors that have affected household well-being differently across the agro-climatic zones can be identified, this study adopts the analytical framework that the labor market is the main transmission process determining whether economic growth will result in the alleviation of poverty. Using the notion of employment as the nexus between growth and poverty, there are two broad categories of proximate causes of poverty: underemployment (the quantity of employment is inadequate) and low returns to labor (earnings per unit of employment is inadequate). For growth to be able to reduce poverty, the nature of the growth process must be such that the forces creating underemployment and low returns to labor are weakened (Osmani, 2004). This can happen with the expansion of an economy's production potential and the extent to which growth in output expands the scope for improving the quantity and quality of employment the employment potential. The greater the expansion of the employment potential, the greater will be the opportunity for reducing underemployment and raising the returns to labor (Osmani, 2004).

Economic activities, generated through rapid growth and the employment potential, can create greater opportunities for workers to increase their income; and while the overall employment intensity of growth does not matter for poverty reduction, the sectoral pattern of employment growth and productivity growth is vital (Gutierrez et a1., 2007). However, extracting some benefit from these opportunities depends on the correspondence between the structure of these opportunities and the structure of capabilities possessed by the poor. The greater the degree of correspondence, the more extensively will the poor be able to integrate into the processes of economic expansion and the faster will be the rate of poverty reduction (Osmani, 2004).

The standard development discourse suggests that, with economic growth, the structure of employment changes - a shift from agriculture to industry and the services sector. Wage and salaried work becomes more dominant. These changes in the employment structure reduce poverty because wage and salaried workers are often considered less vulnerable.

The rural areas of Pakistan are not homogeneous in cropping patterns, households' access to land, provision of health and education services, proximity to cities and the structure of employment including 
access to overseas labor markets, particularly in the Middle East. This diversity in the rural areas shows that the structure of employment and other socio-economic channels through which economic growth trickles down to improve the living standard of the poor varies across the regions. More than half of the rural population is landless. In those rural regions, where poverty is high such as southern Punjab, employment prospects in industry and the services sector are lower than the regions that are better connected to major centers of growth (cities).

The pattern of urbanization in Punjab has generated two urban systems that have helped to connect the rural population with urban jobs. One such system is found in Lahore and its surrounding districts where industries are interlinked and the rural population of these districts has access to urban centers through good road networks. This rural-urban linkage is likely to have helped the rural population to improve their living standards through job opportunities in these centers and the sale of their agricultural products in urban markets. A second urban corridor has been developed in north Punjab by establishing the capital, Islamabad, alongside Rawalpindi, resulting in an increase in the size of the twin cities that has generated a lot of opportunities for nearby areas. They have integrated their rural population as well as populations from surrounding districts, including Jhelum, Chakwal and Attock, by providing them employment opportunities, mainly in the services sector. Moreover, a triangle of three districts, Sialkot, Gujrat and Gujranwala, where light industries are concentrated, is providing better employment opportunities to rural residents. However, it is difficult to find this type of strong linkage between the rural population and urban centers among the cotton/wheat and low intensity zones of Punjab, resulting in a concentration of workers in low-paid jobs (low returns to labor).

Moreover, migration is almost universally argued to be beneficial, allowing individuals to seek out opportunities in new places and, through remittances, to increase private investment in the places they leave (Phillipson, 2005). Pakistan has a long history of sending its workers overseas for employment particularly to the Middle East. But the participation of the poorest regions of the country in this migration has been historically low, leading to regional inequalities in remittances and their effects on poverty. In short, this study considers that the employment structure can largely explain the regional variations in rural poverty in the context of opportunities provided to them in the form of both urbanization and overseas migration. 


\section{Recent Evidence on Poverty in Rural Punjab}

\subsection{Data and Methodology}

In August 2007, PIDE conducted a survey, under the Sustainable Livelihood in Barani Area Punjab (SLBAP) project, covering 647 households in ten districts of Punjab - Rawalpindi, Chakwal, Jhleum, Gujrat, Sialkot, Narowal, Khoshab, Minawali, Bhakkar and Layya. This survey is not representative for any geographical area and has not exactly used the HIEStype consumption module, which is commonly utilized in Pakistan for poverty estimation. It however contains data on major components required for poverty estimation, including food items, fuel and utilities, housing, frequent nonfood expenses (household laundry and cleaning personal care products and services) and other nonfood expenses (clothes, footwear, education, and health related expenses). The PIDE/SLBAP survey has collected information on more than 40 food and non-food items sufficient for poverty estimation.

This study has used the official poverty line after inflating it for the 2007 period. Using the PIHS 1998-99 data, the Planning Commission estimated absolute poverty line as Rs. 673.54 per month per adult equivalent. The Commission has already adjusted the poverty line for the 2000/01 and 2004/05 periods using the Consumer Price Index (CPI). In 2004/05, the official poverty line was Rs. 878.64 per month per adult equivalent. For the present study, it has been adjusted by using the CPI for the 2007 period, when the PIDE/SLBAP survey was carried out. The adjusted poverty line for 2007 is calculated as Rs. 1023 per month per adult equivalent. ${ }^{3}$

For this study, the ten districts covered in the PIDE/SLBAP survey are divided into three zones: barani Punjab consisting of Rawalpindi, Jhelum and Chakwal districts; the rice/wheat zone including three districts, Sialkot, Narowal and Gujrat; and the low intensity zone consisting of four districts - Mianwali, Khushab, Bhakkar and Layya. This zonal classification matches largely with the agro-climatic classification of rural areas by Pinckney (1989). However, the poorest districts of cotton/wheat and low intensity zones, D. G. Khan, Rajanpur, Muzaffargarh, Rahim Yar Khan and Bahawalpur (see Appendix Table-1), have not been covered in the PIDE/SLBAP Survey. Poverty is thus likely to be underestimated for the low intensity zone.

\footnotetext{
${ }^{3}$ While adjusting household consumption expenditure in order to get per adult equivalent expenditure, this study has used an equivalent scale that gives a weight of 0.8 to individuals younger than 15 years and 1 for all other individuals.
} 


\subsection{Poverty Profile, 2007}

The incidence of poverty based on the 2007 PIDE/SLBAP survey is presented in Table-1. The overall incidence in ten surveyed districts is 19.2 percent in 2007; approximately one-fifth of the sampled rural population was living below the poverty line. Zone-level poverty estimates show that the incidence of poverty is lowest in barani districts $(15.6 \%)$ and it is highest in the rice/wheat zone (22.6\%). However, there is only a three percentage point difference between the low intensity (18.9\%) and rice/wheat $(22.6 \%)$ zones. As noted above, relatively low poverty in the 'low intensity' zone is due to the exclusion of the poorest districts e.g. Rajanpur and Muzaffargarh. Table- 1 also presents information on the poverty gap and poverty severity; the overall poverty gap is 3.80 percent and severity of poverty is 1.29 percent, compared to the figures 5.64 percent and 1.77 percent respectively in rural Pakistan according to the 2004/05 PSLM survey (GoP, 2007). Low values of both poverty gap and severity of poverty indicate that most of the poor cluster around the poverty line.

Table-1: Head Count Ratios, Poverty Gap and Severity by Zones, 2007

\begin{tabular}{lccc}
\hline \multicolumn{1}{c}{ Zones } & $\begin{array}{c}\text { Head Count } \\
\text { Ratio }\end{array}$ & Poverty Gap & Poverty Severity \\
\hline Overall & 19.2 & 3.80 & 1.29 \\
Barani Rawalpindi Zone & 15.6 & 2.73 & 0.82 \\
Rice/Wheat Zone & 22.6 & 4.71 & 1.49 \\
Low Intensity Zone & 18.9 & 3.79 & 1.43 \\
\hline
\end{tabular}

Source: PIDE/SLBAP Survey, 2007

The findings of the PIDE/SLBAP survey are not claimed to be representative or strictly comparable with other studies. However, they support the earlier work that poverty in barani Punjab remains low compared to other regions. In terms of the poverty profile, the results of the $2007 \mathrm{PIDE} / \mathrm{SLBAP}$ survey also support the earlier research. For instance, the highest incidence of poverty is found among the landless population and the poverty incidence declines with increases in landholdings and almost vanishes in large landholdings. The importance of livestock in poverty reduction is also evident from the PIDE/SLBAP survey; poverty among those who owned 5 or more animals was only 8.5 percent compared to 28 percent among those who did not own any livestock. It appears that 'natural capital', 
represented by the ownership of land and financial capital in the form of livestock, has a very strong association with poverty.

As expected, poverty was lower in households headed by literate persons compared to households headed by non-literate persons. The educational attainment of household heads was negatively related to the incidence of poverty. Literacy of the head of household has also a significant and negative association with both chronic and transitory poverty (Arif and Bilquees, 2008); human capital thus improves the quality of labor as an asset and is the key element in contexts where access to material assets is highly constrained (CPRC, 2005).

Finally, the 2007 PIDE/SLBAP survey showed that family size was positively associated with the incidence of poverty. Large households were more likely to be poor than small households. The incidence of poverty for the largest households was more than three times the incidence for the smallest households. Larger households in terms of size are likely to have more young children and dependents. The incidence of poverty is usually higher among households with a higher dependency ratio.

\section{Understanding Poverty Differences in Rural Punjab?}

The real question is how to explain regional/zonal differences in rural poverty. In other words, why is poverty considerably lower in barani areas than in other regions of Punjab? This study has first examined land inequality and landlessness across the regions to understand poverty differentials. It then has explored three areas, urbanization, overseas migration and employment structure, as the factors affecting poverty differently across the regions/zones.

\subsection{Land Inequality and Poverty Differences Across Regions ${ }^{4}$}

The ownership of assets, particularly of land and livestock, can be a critical means of alleviating rural poverty. But the ownership of land is highly unequal in Pakistan; only less than half of all rural households

\footnotetext{
${ }^{4}$ This study has not analyzed the role of agricultural growth in explaining the regional poverty differences since it is well-researched by Malik (2005). For example he shows from the Agriculture Census for 2000 that, as farm size increases, people tend to grow sugarcane in Muzaffargarh, and rice and sugarcane in Bahawalpur, Rahim Yar Khan and Bahawalnagar. However, in Rahim Yar Khan, the extent of crop diversification is less than that in Bahawalnagar, indicating that, in case of crop failure, households in these districts are more vulnerable. These households have neither enough resources for crop diversification nor access to opportunities for off-farm employment. However, there are few alternative opportunities for supplementing their income.
} 
own any agricultural land, while the top 2.5 percent of the households account for over 40 percent of all land owned. Both landlessness and the skewed distribution of land are rightly considered the major obstacles hindering the reduction in rural poverty. There has been no change in the Gini coefficient for land ownership; it has remained around 0.66 during the last three decades (World Bank, 2006). In the cotton/wheat zone of Punjab where poverty is high, the Gini coefficient for land ownership is also very high. Within the cotton/wheat zone or southern Punjab, the highest incidence of land inequality is found by Malik (2005) in Muzaffargarh (0.70), followed by Multan (0.65). Rahim Yar Khan and Vehari, the other cotton-producing districts, also exhibit highly unequal (0.62 and 0.60) land distribution.

However, there is little empirical evidence that landlessness or/and land inequality are the decisive factors in explaining the regional differences in rural poverty. Based on the 2004-05 survey, this study has found no marked differences between barani Punjab and the cotton/wheat zones in terms of Gini coefficients or landlessness (Table-2). The land skewedness is found to be rather high in barani Punjab than in other rural zones of the province. The Pakistan Socioeconomic Living Standard Measurement (PSLM) may not be a very relevant data source for the assessment of land distribution. It however does not indicate a considerable variation across zones in landlessness or land distribution. So while access to land is very strong actor in explaining poverty differentials across households in any area/zone, it may not be the crucial factor in explaining inter-regional variations in poverty levels.

Table-2: Landlessness (\% Households Without Land Ownership) and GINI for Land Ownership by Zone

\begin{tabular}{lcc}
\hline \multicolumn{1}{c}{ Zones } & Landlessness (\%) & GINI for Land Ownership \\
\hline Rice/Wheat Zone & 58.1 & 0.647 \\
Cotton-Wheat Zone & 52.4 & 0.589 \\
Mixed Zone & 57.5 & 0.645 \\
Low Intensity Zone & 37.9 & 0.549 \\
Barani Zone & 50.0 & 0.823 \\
\hline
\end{tabular}

Source: PSLM 2004/05. 


\subsection{Urbanization and Regional Poverty}

One of the major arguments in the literature regarding the lower levels of poverty in rural barani Punjab zone compared to other zones is its integration with the prosperous urban centers and strong linkages to the services sector. But this has not been systematically examined. The earlier work of Arif (2003) based on stem-and-leaf display of district-wise 1998 census data for the whole country shows the great concentration of districts with less than 30 percent urban population. Districts that are less than 30 percent urban are mainly located in Southern Punjab, NWFP, Sindh and Balochistan.

Table-3 (column 3) presents data on urbanization and shows that out of 15 districts located in the cotton/wheat and low intensity zones of Punjab, 13 districts had in 1998 less than 20 percent urban population; in fact the figure is less than 15 percent in 6 districts. In remaining three zones of Punjab (barani, mixed and rice/wheat), consisting of 20 districts in total, only 4 had less than 20 percent of urban population. In barani districts, the level of urbanization is particularly high in Islamabad, Rawalpindi and Jhelum.

In the northern and Central Punjab districts, large rural centers having urban characteristics have also developed. This development has not generally taken place in the districts of Southern Punjab. For example, based on the evaluation of the 1998 population census, Arif (2003) identified that 361 rural localities inhabited by more than 5000 persons were better than many small urban centers in terms of the urban related characteristics such as water supply, literacy and non-farm employment. There is a great concentration of these urban-type rural localities in districts of Central and Northern Punjab including Faisalabad, Gujranwala, Sheikhupura, Rawalpindi and Attock. When these localities are taken into account, central Punjab and barani Punjab appear to be more urbanized (Column-4, Table-3), but with no real effect on the Southern Punjab districts.

As noted in Section-3, the pattern of urbanization in Punjab has generated two urban systems in the central and northern areas, which have helped to integrate the rural population with urban centers. It is difficult to find this same type of strong integration between the rural population and urban centers among the cotton/wheat and low intensity zones of Punjab. 
Table-3: Percentage of Distribution Urban Population by Agro-Climatic Zones, 1998

\begin{tabular}{|c|c|c|c|}
\hline $\begin{array}{l}\text { Agro- } \\
\text { Climatic } \\
\text { Zones }\end{array}$ & Districts & $\begin{array}{c}\text { \%age of Urban } \\
\text { Population }\end{array}$ & $\begin{array}{c}\text { \%age Urban Population } \\
\text { after adjusting Rural } \\
\text { Population }\end{array}$ \\
\hline 1 & 2 & 3 & 4 \\
\hline \multirow{9}{*}{$\begin{array}{l}\text { Rice/Wheat } \\
\text { Punjab }\end{array}$} & Sialkot & 26.2 & 31.5 \\
\hline & Gujrat & 27.7 & 29.2 \\
\hline & Gujranwala & 50.5 & 58.3 \\
\hline & Sheikhupura & 26.2 & 36.2 \\
\hline & Lahore & 82.4 & 89.9 \\
\hline & Kasur & 22.8 & 24.6 \\
\hline & Narowal & 12.2 & 12.8 \\
\hline & Mandi Bahauddin & 15.2 & 17.8 \\
\hline & Hafizabad & 27.3 & 28.5 \\
\hline \multirow[t]{6}{*}{ Mixed Punjab } & Sargodha & 28.1 & 28.5 \\
\hline & Khushab & 25.3 & 26.4 \\
\hline & Jhang & 23.4 & 25.3 \\
\hline & Faisalabad & 42.7 & 48.2 \\
\hline & Toba Tek Singh & 18.8 & 19.6 \\
\hline & Okara & 23.0 & 23.7 \\
\hline \multirow{9}{*}{$\begin{array}{l}\text { Cotton/Wheat } \\
\text { Punjab }\end{array}$} & Sahiwal & 16.4 & 17.6 \\
\hline & Bahawalnagar & 19.1 & 19.1 \\
\hline & Bahawalpur & 27.3 & 27.3 \\
\hline & Rahim Yar Khan & 19.6 & 19.9 \\
\hline & Multan & 42.2 & 46.1 \\
\hline & Vehari & 16.0 & 16.0 \\
\hline & Lodhran & 14.5 & 15.2 \\
\hline & Khanewal & 17.6 & 17.6 \\
\hline & Pakpattan & 14.2 & 15.7 \\
\hline Low Intensity & D. G. Khan & 13.9 & 17.5 \\
\hline
\end{tabular}




\begin{tabular}{llcc} 
Punjab & Rajanpur & 14.5 & 14.5 \\
Muzaffargarh & 12.9 & 13.8 \\
Leiah & 12.9 & 12.9 \\
Mianwali & 20.8 & 30.3 \\
Bhakkar & 16.0 & 16.0 \\
Barani Punjab Attock & 21.3 & 26.9 \\
Jhelum & 27.7 & 27.7 \\
Rawalpindi & 53.2 & 59.9 \\
Islamabad & - & 69.1 \\
Chakwal & 12.2 & 16.7 \\
\hline
\end{tabular}

Note: Islamabad is included in barani Punjab for this study

Source: Pickney (1989); Arif (2003).

\subsection{Overseas Migration}

Approximately 4 million Pakistanis were abroad in 2004; about half of them (48\%) were in the Middle East while 28 percent and 21 percent of overseas Pakistanis were in Europe and North America. Within regions, there was heavy concentration in a few countries: Saudi Arabia and United Arab Emirates in the Middle East; United Kingdom in Europe; and United States of America and Canada in North America.

According to official estimates, about 1.9 million Pakistanis were in the Middle East in 2004. Data on the annual placement of Pakistanis in the region show four important dimensions. First, during the last three decades the annual placement of Pakistanis in the Middle East fluctuated substantially, peaking first in 1977 and then in 1981. After the 1990 Gulf War, the placement reached a record level of 195,000. In 2003 and 2007, it exceeded 200,000. Second, Saudi Arabia has provided the most employment opportunities to those Pakistanis who had a chance to emigrate to the region. However, the share of Pakistanis going to the UAE has gradually increased and, more recently, the majority of workers have found employment in this country. Kuwait and other Middle Eastern countries also remain among the common destinations of workers. Third, the skill composition of Pakistani workers in the Middle East has hardly changed during the last three decades. The unskilled category remains the dominant category, followed by skilled, semi-skilled and professional workers. The 
unskilled workers are more likely than others to be less educated and vulnerable to exploitative practices of recruitment.

The fourth feature, which is directly related to the objectives of this study, is that Middle East migration is not drawn evenly from across the country. Recent data show that sixty percent of Pakistanis in the Middle East migrated from only 20 districts, with heavy concentration in north and central Punjab, NWFP, and only Karachi in Sindh and a couple of districts in Southern Punjab. Table-4 shows that all four districts of barani Punjab zone - Rawalpindi, Attock, Chakwal and Jhelum - are among the top 20 districts, and 12 percent of all emigrants who went to the Middle East during 2001-06 period were drawn from these districts. Moreover, the majority of the more than 1000 registered overseas employment promoters are located in the Rawalpindi region. The share of six districts located in the rice/wheat and mixed Punjab zones in overseas migration was 22 percent (Table-4). While only two districts from Southern Punjab-Multan and D. G. Khan - were among the top 20 high-migration districts, no district from the low intensity zone was found. The ranking of the 20 high-migration districts for 1980-2000 periods is not different from the ranking based on the recent data (Table-4).

So what is the lesson? Almost all empirical studies carried out in developing countries including Pakistan have shown a strong linkage between low levels of poverty and overseas migration primarily through remittances. Region/zones which are relatively better in Punjab, having tapped the opportunity of emigration, have been able to attract remittances from abroad (Table-5). This has also probably encouraged the local labor force to enhance their skill levels to compete in the overseas labor market. 
Table 4: Overseas Migrants by Districts of Origin

\begin{tabular}{|c|c|c|c|c|c|c|c|}
\hline \multicolumn{6}{|c|}{$1981-2000$} & \multicolumn{2}{|c|}{$2001-06$} \\
\hline $\begin{array}{l}\text { Ran- } \\
\text { king }\end{array}$ & $\begin{array}{l}\text { Name of the } \\
\text { District }\end{array}$ & $\begin{array}{l}\text { Migrants } \\
\text { (Number) }\end{array}$ & $\begin{array}{c}\text { \% Share } \\
\text { in Total } \\
\text { Migration }\end{array}$ & $\begin{array}{l}\text { Ran- } \\
\text { king }\end{array}$ & $\begin{array}{l}\text { Name of the } \\
\text { District }\end{array}$ & $\begin{array}{l}\text { Migrants } \\
\text { (Number) }\end{array}$ & $\begin{array}{c}\text { \% Share } \\
\text { in Total } \\
\text { Migration }\end{array}$ \\
\hline 1 & Karachi & 187631 & 8.25 & 1 & Rawalpindi & 72252 & 7.31 \\
\hline 2 & Rawalpindi & 140404 & 6.17 & 2 & Gujrat & 54522 & 5.52 \\
\hline 3 & Lahore & 137445 & 6.04 & 3 & Dir & 51490 & 5.21 \\
\hline 4 & Gujrat & 124598 & 5.48 & 4 & Karachi & 50929 & 5.15 \\
\hline 5 & Sialkot & 117139 & 5.15 & 5 & Sialkot & 50561 & 5.11 \\
\hline 6 & Dir & 96027 & 4.22 & 6 & Swat & 40518 & 4.10 \\
\hline 7 & Gujranwala & 83351 & 3.67 & 7 & Lahore & 37438 & 3.79 \\
\hline 8 & Swat & 73806 & 3.25 & 8 & Gujranwala & 30294 & 3.06 \\
\hline 9 & Faisalabad & 73766 & 3.24 & 9 & Faisalabad & 25061 & 2.54 \\
\hline 10 & Peshawar & 67853 & 2.98 & 10 & $\begin{array}{l}\text { Dera Ghazi } \\
\text { Khan }\end{array}$ & 21715 & 2.20 \\
\hline 11 & Mardan & 57687 & 2.54 & 11 & Swabi & 20463 & 2.07 \\
\hline 12 & Kohat & 55214 & 2.43 & 12 & Peshawar & 19452 & 1.97 \\
\hline 13 & Jhelum & 50551 & 2.22 & 13 & Mardan & 18517 & 1.87 \\
\hline 14 & Multan & 45303 & 1.99 & 14 & Chakwal & 17128 & 1.73 \\
\hline 15 & D. G Khan & 41570 & 1.83 & 15 & Kohat & 16614 & 1.68 \\
\hline 16 & Abbottabad & 41326 & 1.82 & 16 & Sheikhupura & 15550 & 1.57 \\
\hline 17 & Attock & 39760 & 1.75 & 17 & Jhelum & 15348 & 1.55 \\
\hline 18 & Mirpur & 38799 & 1.71 & 18 & Attock & 15098 & 1.53 \\
\hline 19 & Kotli & 38597 & 1.70 & 19 & Poonch & 14879 & 1.51 \\
\hline 20 & Bannu & 37135 & 1.63 & 20 & Multan & 14174 & 1.43 \\
\hline 21 & Sub-total (1-20) & - & 61.3 & 21 & Sub-total (1-20) & - & 59.9 \\
\hline 22 & $\begin{array}{l}\text { Sub-total } \\
\text { (others) }\end{array}$ & - & 38.7 & 22 & $\begin{array}{l}\text { Sub-total } \\
\text { (others) }\end{array}$ & - & 40.1 \\
\hline 23 & Total & - & 100 & 23 & Total & - & 100 \\
\hline
\end{tabular}

Source: Bureau of Emigration, Islamabad. 
Table 5: Sources of Income (\% age), 2007.

\begin{tabular}{|c|c|c|c|c|c|c|c|c|c|c|}
\hline $\begin{array}{l}\text { Climate- } \\
\text { Zone }\end{array}$ & $\begin{array}{l}\text { Wages/ } \\
\text { Salaries }\end{array}$ & $\begin{array}{l}\text { Non- } \\
\text { Form } \\
\text { Income }\end{array}$ & $\begin{array}{c}\text { Agri. } \\
\text { Crop } \\
\text { Income }\end{array}$ & $\begin{array}{l}\text { Lives- } \\
\text { Stock } \\
\text { Income }\end{array}$ & $\begin{array}{c}\text { Sale of } \\
\text { Pro- } \\
\text { perty }\end{array}$ & $\begin{array}{l}\text { Rental } \\
\text { income }\end{array}$ & $\begin{array}{c}\text { Remit- } \\
\text { tances } \\
\text { Abroad } \\
\text { Pak. } \\
\end{array}$ & $\begin{array}{c}\begin{array}{c}\text { Remit- } \\
\text { tance } \\
\text { within } \\
\text { Pak. }\end{array} \\
\end{array}$ & $\begin{array}{l}\text { Other } \\
\text { Income }\end{array}$ & All \\
\hline $\begin{array}{l}\text { Rice/ } \\
\text { Wheat } \\
\text { Punjab }\end{array}$ & 57.60 & 3 & 13.88 & 1.97 & 0.01 & 0.98 & 18.09 & 1.38 & 2.59 & 100 \\
\hline $\begin{array}{l}\text { Mixed } \\
\text { Punjab }\end{array}$ & 47.86 & 3.79 & 30.43 & 6.68 & 1.54 & 4.99 & 2.68 & 0.00 & 2.02 & 100 \\
\hline $\begin{array}{l}\text { Low } \\
\text { Intensity } \\
\text { Punjab }\end{array}$ & 73.58 & 3.48 & 12.47 & 3.56 & 0.17 & 1.13 & 2.50 & 0.68 & 2.43 & 100 \\
\hline $\begin{array}{l}\text { Barani } \\
\text { Punjab }\end{array}$ & 69.55 & 4.87 & 2.19 & 3.00 & 0.02 & 0.24 & 11.62 & 1.92 & 6.60 & 100 \\
\hline Total & 64.99 & 3.98 & 10.66 & 3.03 & 0.15 & 1.03 & 10.98 & 1.29 & 3.87 & 100 \\
\hline
\end{tabular}

Source: PIDE computed form the SLABP survey, 2007.

\subsection{Labor Market Indicators}

Tables- 6 and Table-7 set out data on three labor market indicators: industrial composition of rural employed labor force, their occupational distribution, and employment status across agro-climatic zones. While Table- 6 shows the statistics as computed from the PSLM 2004/05, the data reported in Table-7 is from the 2007 PIDE/SLBAP survey. The two data sources lead to the same findings. However, data on occupational composition from the PIDE/SLBAP survey provide some more interesting detail on job opportunities for the barani region.

Several conclusions can be drawn from Tables-6 and Table-7. First, about a quarter of the rural labor force (24\%) from barani Punjab zone is engaged in the social and personal services sector.' The corresponding percentages were 15 and 11 for the cotton/wheat and low intensity zones, respectively. Thus the 1abor force from barani districts of Punjab has the opportunities to work in the urban services sector, mainly in Rawalpindi and Islamabad. Second, as expected, there is a high dependency of the rural labor force on the agriculture sector (about 60\%) in two poorer regions, cotton/wheat and low intensity. In contrast, less than one-third (32\%) of the

${ }^{5}$ The PIDE/SLBAP survey shows an even higher percentage in services sector (Table $6 a)$. 
rural labor force in the barani districts is associated with the agricultural sector. Third, in central Punjab, one-tenth of the rural labor force is employed in the manufacturing sector compared to only 2.7 percent in the barani zone. It corroborates our earlier discussion that while interlinked industrialization in urban areas of central Punjab is the source of employment for rural population, it is the urban services sector in barani districts that has integrated the rural population. Fourth, there is relatively greater reliance of the barani zone on the construction sector. The role of trade/business appears to be more important in the rice/wheat and mixed Punjab zones.

The occupational classification of the rural labor force across the agro-climatic zones is the mirror of their industrial composition. However, the additional information provided by the PIDE/SLBAP 2007 survey is interesting. Table-7b shows that one-tenth of rural labor force in the barani zone is employed in the armed services and a similar proportion (8.6\%) have jobs in different government departments. While the bulk of this educated rural labor force associated with government departments is likely to be located in rural areas in the health and education sectors, many of them are likely to be working in the twin cities of Rawalpindi and Islamabad. Very interestingly, the PIDE/SLBAP survey shows the crucial role of the private sector in providing employment to the rural population; 21 percent were employed in this sector. However, it needs further research.

With respect to employment status, the striking difference across the zones is in regards to the proportion of the rural labor force working as "unpaid family helpers", which is considerably low in the barani zone; only 19 percent compared to 34 percent and 26 percent respectively in the cotton/wheat and low intensity zones (Table-7c). According to the PIDE/SLBAP survey, only 8 percent of the labor force was in the category of "unpaid family helpers". While it is beyond the scope of this exploratory work to link this phenomenon with regional labor market conditions, it does indicate the limited job opportunities available in the non-farm sector of the poorer regions of Punjab e.g., cotton/wheat and low intensity zones. 
Table-6a: Percentage Distribution of the Employed Rural Labor Force by Industry and Zones

\begin{tabular}{lccccc}
\hline \multicolumn{1}{c}{ Industry } & $\begin{array}{c}\text { Rice- } \\
\text { Wheat }\end{array}$ & $\begin{array}{c}\text { Mixed } \\
\text { Punjab }\end{array}$ & $\begin{array}{c}\text { Cotton } \\
\text { Wheat } \\
\text { Punjab }\end{array}$ & $\begin{array}{c}\text { Low } \\
\text { Intensity } \\
\text { Punjab }\end{array}$ & $\begin{array}{c}\text { Barani } \\
\text { Punjab }\end{array}$ \\
\hline Agriculture, Forestry, Fishing & 45.9 & 54.4 & 58.9 & 58.7 & 31.8 \\
Mining \& Quarrying & & 0.0 & 0.2 & 0.4 & 0.5 \\
Manufacturing & 12.1 & 9.6 & 4.9 & 7.1 & 1.5 \\
Electricity & 0.7 & 0.7 & 0.2 & 0.2 & 0.6 \\
Construction & 5.9 & 4.3 & 6.7 & 8.7 & 11.4 \\
Wholesales \& Retail Trade & 14.2 & 9.1 & 9.1 & 6.2 & 6.2 \\
Transport \& Storage & 4.0 & 2.4 & 3.0 & 2.3 & 4.6 \\
Real Estate \& Insurance & 0.3 & 0.1 & 0.0 & & \\
Social \& Personal Service & 15.3 & 18.1 & 14.7 & 11.1 & 24.0 \\
Others & 1.6 & 1.3 & 2.1 & 5.2 & 19.3 \\
Total & $\mathbf{1 0 0 . 0}$ & $\mathbf{1 0 0 . 0}$ & $\mathbf{1 0 0 . 0}$ & $\mathbf{1 0 0 . 0}$ & $\mathbf{1 0 0 . 0}$ \\
\hline
\end{tabular}

Source: Computed from PSLM 2004/05.

Table-6b: Percentage Distribution of the Employed Rural Labor Force by Occupation and Agro-Climate Zone

\begin{tabular}{lccccc}
\hline \multicolumn{1}{c}{ Occupation } & $\begin{array}{c}\text { Rice- } \\
\text { Wheat }\end{array}$ & $\begin{array}{c}\text { Mixed } \\
\text { Punjab }\end{array}$ & $\begin{array}{c}\text { Cotton } \\
\text { Wheat } \\
\text { Punjab }\end{array}$ & $\begin{array}{c}\text { Low } \\
\text { Intensity } \\
\text { Punjab }\end{array}$ & $\begin{array}{c}\text { Barani } \\
\text { Punjab }\end{array}$ \\
\hline Senior Officials/Managers & 1.0 & 0.5 & 0.8 & 0.2 & 0.1 \\
Professionals & 2.9 & 1.9 & 2.1 & 1.8 & 3.7 \\
Tech. and Ass. Professionals & 2.3 & 1.1 & 0.8 & 0.5 & 1.8 \\
Clerks & 1.1 & 1.3 & 0.5 & 0.4 & 2.4 \\
Service, Shop, Sales Workers & 21.7 & 20.9 & 20.4 & 23.4 & 22.6 \\
Skilled Agriculture \& Fishery & 44.7 & 49.5 & 48.4 & 47.6 & 31.2 \\
Craft \& Trade Workers & 6.1 & 3.5 & 1.8 & 4.4 & 0.6 \\
Plant Machinery Operators & 4.5 & 4.8 & 2.4 & 1.2 & 2.4 \\
Elementary Occupation & 15.7 & 16.6 & 22.8 & 20.5 & 35.1 \\
Total & $\mathbf{1 0 0 . 0}$ & $\mathbf{1 0 0 . 0}$ & $\mathbf{1 0 0 . 0}$ & $\mathbf{1 0 0 . 0}$ & $\mathbf{1 0 0 . 0}$ \\
\hline
\end{tabular}

Source: Computed from PSLM 2004/05. 
Table-6c: Percentage Distribution of the Employed Rural Labor Force by Employment Status and Zones

\begin{tabular}{lccccc}
\hline $\begin{array}{c}\text { Employment } \\
\text { Status }\end{array}$ & $\begin{array}{c}\text { Rice- } \\
\text { Wheat }\end{array}$ & $\begin{array}{c}\text { Mixed } \\
\text { Punjab }\end{array}$ & $\begin{array}{c}\text { Cotton Wheat } \\
\text { Punjab }\end{array}$ & $\begin{array}{c}\text { Low Intensity } \\
\text { Punjab }\end{array}$ & $\begin{array}{c}\text { Barani } \\
\text { Punjab }\end{array}$ \\
\hline Employees & 29.8 & 30.4 & 38.9 & 29.0 & 45.1 \\
Self Employed & 45.4 & 38.4 & 36.2 & 37.4 & 35.3 \\
Employers & 0.3 & 0.1 & 0.1 & 0.1 & 0.7 \\
Unpaid Family & 24.5 & 31.2 & 24.9 & 33.6 & 18.9 \\
Helpers & & & & & \\
Total & $\mathbf{1 0 0 . 0}$ & $\mathbf{1 0 0 . 0}$ & $\mathbf{1 0 0 . 0}$ & $\mathbf{1 0 0 . 0}$ & $\mathbf{1 0 0 . 0}$ \\
\hline
\end{tabular}

Source: Computed from PSLM 2004/05.

Table-7a: Percentage Distribution of the Employed Rural Labor Force by Industry and Zones

\begin{tabular}{lcccc}
\hline \multicolumn{1}{c}{ Industry } & Barani & $\begin{array}{c}\text { Mixed } \\
\text { Punjab }\end{array}$ & $\begin{array}{c}\text { Low } \\
\text { Intensity }\end{array}$ & Total \\
\hline Agriculture, Forestry \& Fishing & 13.9 & 25.1 & 28.5 & 23.9 \\
Mining \& Quarrying & 1.5 & .6 & .3 & .7 \\
Manufacturing & 22.1 & 25.3 & 14.5 & 19.7 \\
Construction & 4.7 & 4.4 & 5.9 & 5.1 \\
Whole Sale/Retail Trade & 4.2 & 4.1 & 2.5 & 3.4 \\
Transport \& Storage & 4.7 & 3.5 & 2.5 & 3.3 \\
Social \& Personal Services & 39.0 & 28.0 & 39.4 & 35.7 \\
Not Defined/Other & 9.9 & 9.1 & 6.5 & 8.2 \\
Total & $\mathbf{1 0 0}$ & $\mathbf{1 0 0}$ & $\mathbf{1 0 0}$ & $\mathbf{1 0 0}$ \\
\hline
\end{tabular}

Source: PIDE computed from the SLBAP Survey, 2007. 
Table-7b: Percentage Distribution of the Employed Rural Labor Force by Occupation and Agro-Climate Zone

\begin{tabular}{lcccc}
\hline \multicolumn{1}{c}{ Occupation } & Barani & Mixed Punjab & Low Intensity & Total \\
\hline Laborer & 35.3 & 42.4 & 32.2 & 36.2 \\
Armed Services & 10.0 & 1.5 & 6.6 & 5.8 \\
Govt. Job & 8.6 & 2.5 & 6.5 & 5.8 \\
Private Service & 21.0 & 17.8 & 17.5 & 18.4 \\
Foreign Services & 1.1 & 1.5 & .5 & .9 \\
Farmer & 8.9 & 23.7 & 22.3 & 19.4 \\
Business/Shopkeeper & 8.6 & 8.5 & 12.0 & 10.1 \\
Other & 6.5 & 2.1 & 2.4 & 3.3 \\
Total & $\mathbf{1 0 0}$ & $\mathbf{1 0 0}$ & $\mathbf{1 0 0}$ & $\mathbf{1 0 0}$ \\
\hline
\end{tabular}

Source: PIDE computed for the SLBAP Survey, 2007.

Table-7c: Percentage Distribution of the Employed Rural Labor Force by Employment Status and Zones

\begin{tabular}{lcccc}
\hline Employment Status & Barani & Mixed Punjab & Low Intensity & Total \\
\hline Employee & 77.4 & 62.5 & 65.1 & 67.3 \\
Employer & - & .2 & .4 & .3 \\
Self-Employee & 10.9 & 17.2 & 19.0 & 16.4 \\
Unpaid Family Helper & 7.8 & 15.5 & 11.6 & 11.9 \\
Others & 3.9 & 4.6 & 3.9 & 4.1 \\
Total & $\mathbf{1 0 0}$ & $\mathbf{1 0 0}$ & $\mathbf{1 0 0}$ & $\mathbf{1 0 0}$ \\
\hline
\end{tabular}

Source: PIDE computed from SLBAP Survey, 2007.

\subsection{Human Capital}

The Population Census 1998 indicated a decline in the intercensal population growth rate from 3.1 percent observed during 1972-81 period to 2.6 percent during 1981-98. This decline has important implications for the 1abor supply through the changing age-structure and resultant dependency ratios. The age structure in Pakistan has shifted more towards youth. The overall share of the working-age population is rising. Because of likely 
declining trends in child dependency during the next 2-3 decades, there will be a relatively low burden on the working-age population. After 2030, however, the expected rapid increase in the elderly population could enhance old age-dependency.

Table- 8 shows that there is a marked difference across the rural zones of Punjab in dependency ratios and family size. The dependency ratio in the barani zone is 0.79 compared to 0.99 and 1.14 respectively for the cotton/wheat and low intensity zones. It shows that the demographic transition is well ahead in the barani zone compared to other zones of the province. Family size is also low in the former.

The illiteracy rate in the "low intensity" zone is double the rate in the barani zone. The situation of the cotton-wheat zone is not different either (Table-8). The proportion of the adult population who has 10 or more years of education is 19 percent in the barani zone and only 9 percent in the cotton-wheat zone. It appears that employment opportunities in the armed forces, government departments and overseas have a favorable impact on enhancing the qualifications of the rural population in the barani zone.

Finally, there seems to be a correspondence, particularly in barani Punjab, between the structure of employment and the capabilities of the rural population, who have been able to integrate into the process of economic growth and reduce the incidence of poverty.

Table-8: Family Size, Dependency Ratio and Education by Zone

\begin{tabular}{lcccc}
\hline \multicolumn{1}{c}{ Zone } & $\begin{array}{c}\text { Family } \\
\text { Size }\end{array}$ & $\begin{array}{c}\text { Dependency } \\
\text { Ratio }\end{array}$ & $\begin{array}{c}\text { \% } \\
\text { Illiterate }\end{array}$ & $\begin{array}{c}\text { \% Having 10 or More } \\
\text { Years of Education }\end{array}$ \\
\hline Rice/Wheat & 7.9 & 0.93 & 40.4 & 14.1 \\
Mixed Punjab & 7.8 & 0.94 & 47.8 & 14.2 \\
Cotton-Wheat & 8.0 & 0.99 & 54.8 & 9.1 \\
Low Intensity & 8.4 & 1.14 & 60.8 & 6.8 \\
Barani Punjab & 6.9 & 0.79 & 31.4 & 18.9 \\
\hline
\end{tabular}

Source: Computed from the PSLM 2004/05. 


\section{Concluding Remarks}

There is convincing evidence that the rural areas of Punjab differ widely in poverty levels, the lowest being in the barani Punjab zone and the highest in cotton/wheat zone of South Punjab. This study has shown four major factors that explain inequalities in poverty levels. First, the rural areas of two zones, barani and rice/wheat, are well integrated with urban settings. This integration has given access to their rural population to work in the industrial sector of the Central Punjab and services sector in North Punjab, primarily Rawalpindi and Islamabad. Second, the belt starting from Lahore to Attock in Punjab has benefited the most from overseas migration. The flow of remittances has helped in reducing poverty levels. Third, the cotton/wheat and low intensity zones still largely depend on the agricultural sector for employment while this dependency is very low in the barani zone, whose inhabitants are able to seek job opportunities in the armed services and government departments. Finally, demographic and social factors including education are less favorable in the cotton/wheat and low intensity zones.

The poor regions of rural Punjab may be targeted to:

1. Enhance rural-urban linkages through both infrastructure development and investment in small and medium enterprises (SMEs) in towns and cities to provide better employment opportunities for the rural labor force of these regions;

2. Encourage establishment of industrial zones;

3. Fill regional gaps in human capital and skill levels by providing better education and health facilities; and

4. Increase access to overseas employment by bringing the poor regions under the official recruitment network. Credit facilities to finance overseas migration may also be given to poor households in poor regions of the province. 


\section{References}

Arif, G. M., 2003, "Urbanization in Pakistan: Trends, Growth and Evaluation of the 1998 Census" in A. R. Kemal, Muhammad Irfan, Naushin Mahmood, (Eds.), Population of Pakistan: An Analysis of 1998 Population and Housing Census, Pakistan Institute of Development Economics, Islamabad.

Arif, G. M., 2006, "Poverty Targeting in Pakistan: The Case of Zakat and the Lady Health Worker Program," in Poverty Strategies in Asia: A Growth Plus Approach. Edited by John Weiss and Haider A. Khan, Edward Elgar Cheltenham, UK.

Arif, G. M., and Munir Ahmad, 2001, "Poverty Across the Agro-Ecological Zones in Rural Pakistan”. Paper presented at the National Workshop on Pro-Poor Intervention Strategies in Irrigated Agriculture in Asia: Pakistan, International Water Management Institute, Lahore, 12 March.

Arif, G.M. and Bilquees, 2008, "Chronic and Transitory Poverty in Pakistan: Evidence from Longitudinal Household Survey”. Submitted for publication in the Pakistan Development Review.

Cheema, Ali, 2008, "Stress on Poverty Reduction" The Daily Dawn, April 7, 2008 .

CPRC., 2005, The Chronic Poverty Report 2004-05. Chronic Poverty Research Centre, University of Manchester, UK.

Government of Pakistan, 2003, National Accounts of Pakistan 2001-02. Islamabad, FBS/Statistics Division.

Government of Pakistan, 2007, Ensuring a Demographic Dividend Unleashing Human Potential in a Globalized World. Ministry of Finance, Government of Pakistan, Islamabad.

Gutierrez Catalina, 2007, Does Employment Generation Really Matter for Poverty Reduction? World Bank, Washington DC.

Irfan, Mohammad, 2008, "Poverty and Natural Resources Management in Pakistan”. Paper presented in the $23^{\text {rd }}$ Annual General Meeting and Conference, Pakistan Institute of Development Economics, Islamabad, March 12-14, 2008. 
Jama1, Haroon, A. J. Khan, I. A. Toor, and N. Anwar, 2003, "Mapping the Spatial Deprivation of Pakistan”. Pakistan Development Review 42 (2): 91-112.

Malik, Sohail J., 2005, "Agricultural Growth and Rural Poverty: A Review of the Evidence," Working Paper No.2, Pakistan Resident Mission Working Paper Series, Asian Development Bank, Islamabad.

Malik, Sohail J., 1992, "Rural Poverty in Pakistan: Some Recent Evidence”. Pakistan Development Review 31(4).

Osmani S. R., 2004, "The Employment Nexus between Growth and Poverty: An Asian Perspective”. University of U1ster, U.K.

Phillipson Rache1, 2005, "Understanding Labour Markets and Poverty Reduction: How May Regional and Spatial Perspectives Help?" A Report for the Urban Rural Change Team Department for International Development.

Pickney, Thomas C., 1989, "The Demand for Public Storage of Wheat in Pakistan”. Research Report 77. IFPRI, Washington, DC.

World Bank, 2006, Development and the Next Generation, WDR 2007. The World Bank, Washington, DC. 
Appendix Table-1: Distribution of Districts by Agro-climatic Zones

\begin{tabular}{|c|c|c|}
\hline & $\begin{array}{l}\text { Agro-Climatic } \\
\text { Zones }\end{array}$ & Districts \\
\hline 1. & Rice/Wheat Punjab & $\begin{array}{l}\text { Sialkot Gujrat Gujranwala Sheikhupura Lahore } \\
\text { Kasur Narowal Mandi Bahauddin Hafizabad }\end{array}$ \\
\hline 2 . & Mixed Punjab & $\begin{array}{l}\text { Sargodha Khushab Jhang Faisalabad Toba Tek } \\
\text { Singh Okara }\end{array}$ \\
\hline 3. & Cotton/Wheat Punjab & $\begin{array}{l}\text { Sahiwal Bahawalnagar Bahawalpur Rahim Yar } \\
\text { Khan Multan Vehari Lodhran Khanewal } \\
\text { Pakpattan }\end{array}$ \\
\hline & Low Intensity Punjab & $\begin{array}{l}\text { D. G. Khan Rajanpur Muzaffargarh Leiah } \\
\text { Mianwali Bhakkar }\end{array}$ \\
\hline & Barani Punjab & Attock Jhelum Rawalpindi Islamabad Chakwal \\
\hline
\end{tabular}

Source: Pickney (1989).

Appendix Table-2: Incidence of Poverty by Agro Climatic Zones of Rural Punjab

\begin{tabular}{lcccccc}
\hline $\begin{array}{l}\text { Agro-Climatic } \\
\text { Zones }\end{array}$ & $\begin{array}{c}\mathbf{1 9 8 4 - 8 5} \\
\mathbf{( 1 )}\end{array}$ & $\begin{array}{c}\mathbf{1 9 8 7 - 8 8} \\
\mathbf{( 2 )}\end{array}$ & $\begin{array}{c}\mathbf{1 9 9 3 - 9 4} \\
\mathbf{( 3 )}\end{array}$ & $\begin{array}{c}\mathbf{1 9 9 8 - 9 9} \\
\mathbf{( 4 )}\end{array}$ & $\begin{array}{c}\mathbf{2 0 0 1 - 0 2} \\
\mathbf{( 5 )}\end{array}$ & $\begin{array}{c}\mathbf{2 0 0 4 - 0 5} \\
\text { (6) }\end{array}$ \\
\hline $\begin{array}{l}\text { Rice/Wheat } \\
\text { Punjab }\end{array}$ & 14.3 & 8.2 & 33.1 & 47.7 & 26.4 & 29.5 \\
Mixed Punjab & 22.7 & 15.9 & 21.0 & 31.4 & 48.9 & 29.6 \\
$\begin{array}{l}\text { Cotton/Wheat } \\
\text { Punjab }\end{array}$ & 29.3 & 21.9 & 25.4 & 36.5 & 55.5 & 36.5 \\
$\begin{array}{l}\text { Low Intensity } \\
\text { Punjab }\end{array}$ & 28 & 27.1 & 2.2 & 32.6 & 54.2 & 20.4 \\
Barani Punjab & 5.7 & 3.9 & 13.8 & 27.5 & 38.3 & 7.2 \\
\hline
\end{tabular}

Source: For Column 1 and 2 Malik (1992); for Column 3 and 4 Arif and Ahmed (2001); for Column 5 Malik (2005); for Column 6 Irfan (2008). 